\title{
First occurrence of Quadrigyrus nickoli (Acanthocephala) in the ornamental fish Hyphessobrycon eques
}

Primeira ocorrência de Quadrigyrus nickoli (Acanthocephala) no peixe ornamental Hyphessobrycon eques

Rodrigo Yudi Fujimoto'; Edilene Santos Almeida²; Daniel Guerreiro Diniz ${ }^{3}$; Jorge Costa Eiras'; Mauricio Laterça Martins ${ }^{5}$

${ }^{1}$ Embrapa Tabuleiros Costeiros, Aracajú, SE, Brasil

${ }^{2}$ Laboratório de Ictioparasitologia e Piscicultura, Universidade Federal do Pará - UFPA, Bragança, PA, Brasil

${ }^{3}$ Laboratório de Investigaçōes em Neurodegeneração e Infecção, Instituto de Ciências Biológicas, Hospital Universitário João de Barros Barreto, Universidade Federal do Pará - UFPA, Belém, PA, Brasil

${ }^{4}$ Departamento de Biologia, and CIIMAR, Faculdade de Ciências, Universidade do Porto, Porto, Portugal

${ }^{5}$ Laboratório AQUOS - Sanidade de Organismos Aquáticos, Departamento de Aquicultura, Universidade Federal de Santa Catarina - UFSC,

Florianópolis, SC, Brasil

Received March 12, 2012

Accepted October 29, 2012

\begin{abstract}
The objective of this work was to report the first seasonal occurrence of the acanthocephalan Quadrigyrus nickoli Schmidt \& Hugghins, 1973 (Quadrigyridae), in the "Mato Grosso" Hyphessobrycon eques (Characidae) (Steindachner, 1882), collected from the Chumucuí River, state of Pará, Brazil. The fish were collected between July 2006 (rainy season) and June 2007 (dry season) and were examined for parasites using pattern techniques. A total of 75 parasites were found in the stomach and intestine. Among 83 fish examined (50 in the dry season and 33 in the rainy season), 22 were parasitized by cystacanths of Q. nickoli. The importance of $H$. eques as a paratenic host for $Q$. nickoli is discussed. This is the first study on the biology of and infection by Q. nickoli occurring in the eastern Amazon region.
\end{abstract}

Keywords: Acanthocephala, Amazon, ornamental fish, Quadrigyrus nickoli, Hyphessobrycon eques.

\section{Resumo}

O objetivo desse trabalho foi registrar a primeira ocorrência sazonal do acantocefala Quadrigyrus nickoli Schmidt \& Hugghins, 1973 (Quadrigyridae) no peixe "Mato Grosso", Hyphessobrycon eques Steindachner, 1882 (Characidae), capturados no Rio Chumucuí, regiāo Bragantina, Pará, Brasil. Os peixes foram coletados no período de julho/2006 a junho/2007 e examinados com técnica padrão para detecção de parasitas. Um total de 75 parasitas foram encontrados no estômago e intestino. Dos 83 peixes capturados (50 na estação seca e 33 na chuvosa), 22 estavam parasitados por cistacantos de Quadrigyrus nickoli. No presente trabalho discute-se a importância do H. eques como hospedeiro paratênico para Quadrigyrus nickoli. Os presentes dados constituem o primeiro estudo sobre a biologia e a infecção de Q. nickoli na Amazônia oriental.

Palavras-chave: Acantocefalos, Amazônia, peixe ornamental, Quadrigyrus nickoli, Hyphessobrycon eques.

\section{Introduction}

The freshwater ornamental fish trade is an important economic activity, especially for fishermen living in small settlements near the Amazonian rivers. According to FAO data (2000), the trade in this kind of fish is worth around three billion US dollars per year, and it is highly likely that these figures will have increased substantially over the last few years. Within Brazil, this trade is especially important in the Amazon basin (states of Amazonas and Pará), and Hyphessobrycon spp. (Characidae) are some of the most valuable species (FREITAS; RIVAS, 2006).

*Corresponding author: Rodrigo Yudi Fujimoto

Embrapa Tabuleiros Costeiros, Av. Beira Mar, 3250, CEP 49025-040, Aracajú,

SE, Brasil

e-mail: ryfujim@hotmail.com
Hyphessobrycon eques (Steindachner, 1882), the jewel tetra, occurs naturally in the Amazon basin, buthas also been introduced into the Mato Grosso wetlands, Paraguay, Bolivia and Argentina (COLE; HARING, 1999), especially in regions with $\mathrm{pH}$ levels between 6.5 and 7.0 , and temperature between $26^{\circ} \mathrm{C}$ and $28^{\circ} \mathrm{C}$. Due to its peculiar red color, it is highly appreciated as an aquarium fish.

In Brazil, there are only a few reports on parasites of wild freshwater ornamental fish. In these few studies, Monogenea and Ichthyophthirius multifliiis were found to be the commonest parasites in Paracheirodon axelrodi and Hyphessobrycon copelandi (Characidae); Carnegiella strigata and Carnegiella marthae (Gasteropelecidae); Ancistrus hoplogenys (Loricariidae); Nannostomus eques and Nannostomus unifasciatus (Lebiasinidae); and Pterophyllum 
scalare (TAVARES-DIAS et al. 2009, 2010). However, data on the seasonality of infection levels are very rare (MARTINS et al., 2000). Despite an increase in the number of such studies over the last few years, due to the expansion of fish exportation to many countries (LUQUE, 2004), knowledge about the parasites of freshwater ornamental fish is still very sparse, especially regarding seasonal data.

Here, we present the first report on the characteristics of infection by the acanthocephalan Quadrigyrus nickoli in Hyphessobrycon eques, caught in the Chumucuí River, Bragança, Pará.

\section{Materials and Methods}

Specimens of Hyphessobrycon eques were caught in the dry season (August 2006 to January 2007) and rainy season (February 2007 to July 2007) (Figure 1) for parasitological analyses. The sampling was done using nets every month in the Chumucuí River, near Bragança, Pará (01 ${ }^{\circ} 12^{\prime} 38.3^{\prime \prime} \mathrm{S}$ and $46^{\circ} 47^{\prime} 31.7^{\prime}$ 'W) between July 2006 and June 2007. Rainfall rates were obtained from Tracuateua Meteorological Station (INMET), and two seasons were defined in accordance with Schaeffer-Novelli and Cintrón (1986): the rainy season (rainfall over $100 \mathrm{~mm}^{3}$ ) and the dry season (rainfall under $100 \mathrm{~mm}^{3}$ ).

The fish were transported alive to the laboratory and were then sacrificed by means of an overdose of anesthetic, weighed, measured (total and standard length) and carefully inspected for parasites as described by Amato et al. (1991) and Eiras et al. (2006). Parasites were identified in accordance with Thacher (2006), and the parasitological indexes of intensity of infection, mean intensity of infection and prevalence were determined as described by Bush et al. (1997).

The parasitological indexes of intensity and prevalence were statistically analyzed using the Bio Estat 4.0 software. The Shapiro-Wilk normality test and outlier test were used to investigate whether the sample presented normal distribution. The t-test for related samples was performed to evaluate the existence of seasonal differences in prevalence and mean intensity values, and Pearson's correlation (correlation matrix) was used to ascertain whether parasitism was influenced by the total and standard length or the weight of the hosts.

\section{Results}

Eighty-three fish specimens were caught: 50 during the dry season and 33 during the rainy season. The total length of the fish ranged from 2.0 to $3.9 \mathrm{~cm}(2.9 \pm 0.48 \mathrm{~cm})$, the standard length from 1.7 to $3.2 \mathrm{~cm}(2.4 \pm 0.40 \mathrm{~cm})$, and the weight from $0.2 \mathrm{~g}$ to $0.89 \mathrm{~g}(0.27 \pm 0.18)$. The results from the Pearson correlation showed that there was no correlation between the parasitological indices and the total and standard length values, or with the weight of $H$. eques (Table 1 ).

Twenty-two out of the 83 fish sampled were parasitized by cystacanths of Quadrigyrus nickoli. This species has four rows of hooks on the proboscis, each row with five hooks. The trunk has four rows of spines, each with 23 to 29 spines. The total number of parasites was 75, of which 67 specimens were located in the stomach and eight in the intestine.

Within the stomach, the parasites presented highest prevalence values (50\%) in July 2006, lowest levels in October 2006, December 2006 and June 2007, and intermediate levels in August 2006 (Figure 2a). The highest value for mean intensity (11.2) was found in July 2006 (Figure 2b).

In the anterior intestine, the acanthocephalan parasite was observed only in July 2007 (14.2\% prevalence, and mean intensity of one parasite/host). In the posterior intestine, the highest prevalence (100\%) was observed in May 2007 (Figure 3a), as was the highest mean intensity (2) (Figure 3b).

A significant difference $(\mathrm{p}<0.05)$ in prevalence values in the middle intestine was found between the two seasons (Figure 4). Data relating to the other parasitological indexes were not statistically different between the seasons.

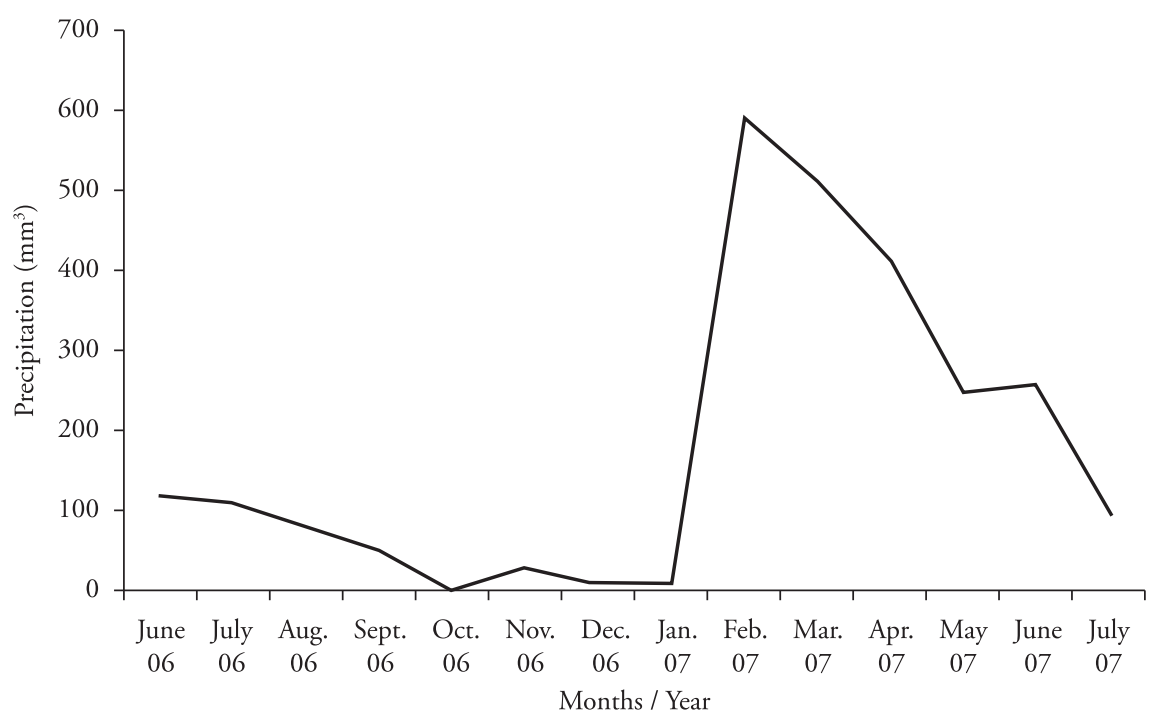

Figure 1. Monthly precipitation in the sampling area from July 2006 to July 2007. Data from Tracuateua Meteorological Station (INMET). 


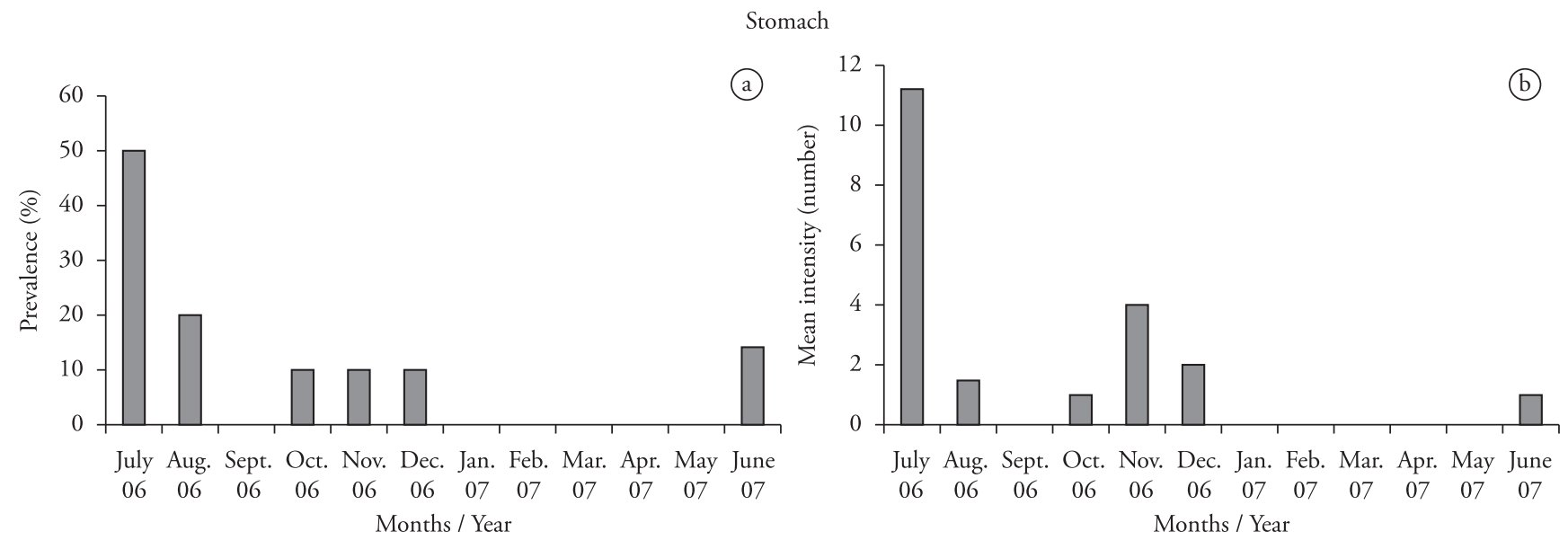

Figure 2. a) Prevalence (\%) and b) mean intensity of Q. nickoli in the stomach of the jewel tetra (Hyphessobrycon eques).
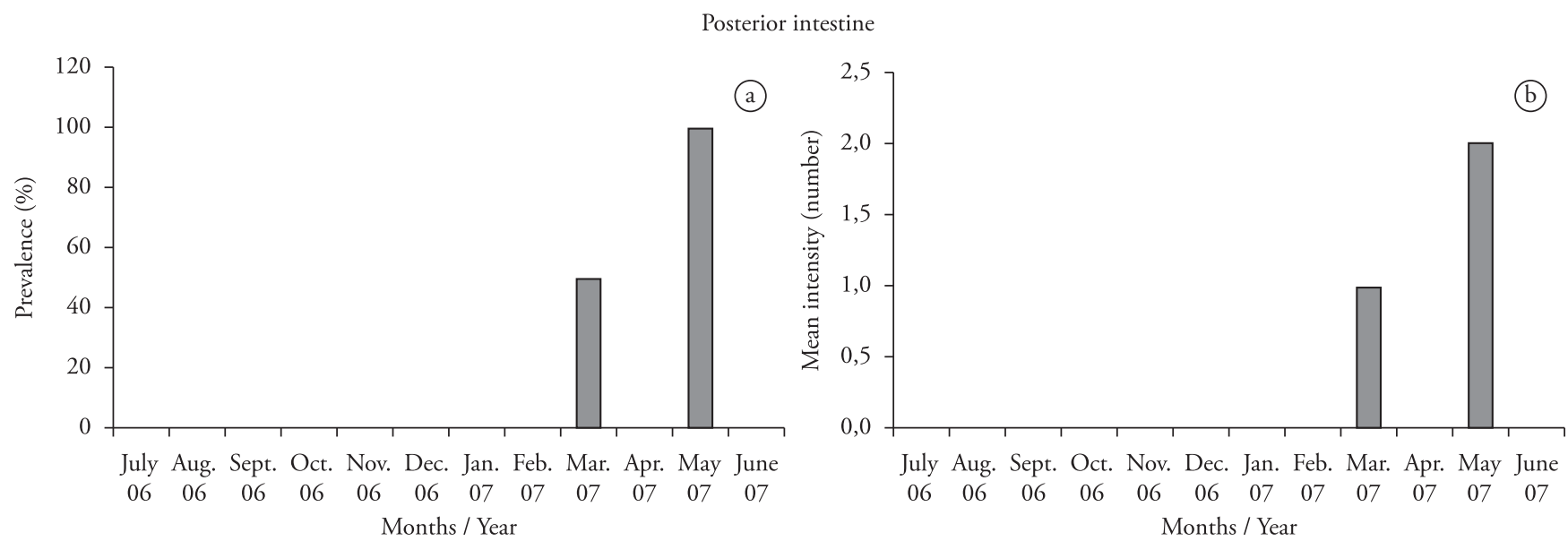

Figure 3. a) Prevalence (\%) and b) mean intensity of Q. nickoli in the posterior intestine of the jewel tetra (Hyphessobrycon eques).

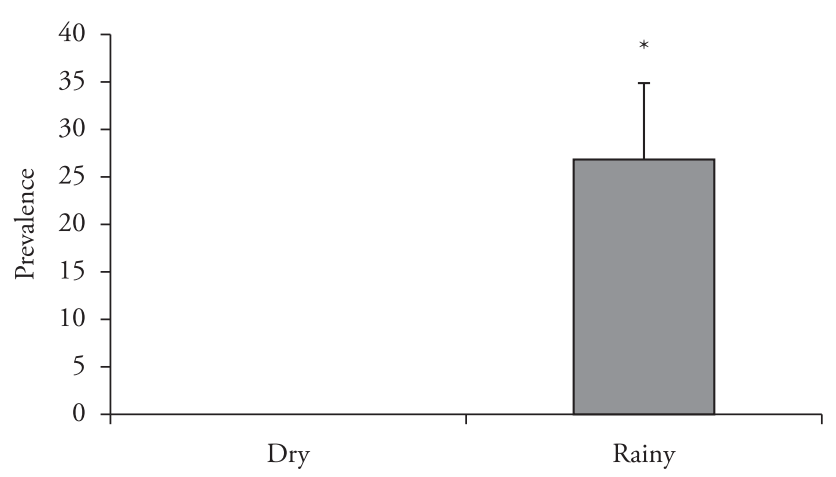

Figure 4. Prevalence (\%) of infection due to Q. nickoli in the middle intestine of the jewel tetra (Hyphessobrycon eques) in the dry and rainy seasons.

\section{Discussion}

Quadrigyrus nickoli was described by Schmidt and Hugghins (1973) as infecting the teleostean Hoplerythrinus unitaeniatus in Peru. Since then, no studies on the biology of this species have been produced. According to the results obtained from the present study, $H$. eques was a paratenic host for $H$. unitaeniatus only if the
Table 1. R values for Pearson's correlation between weight, total and standard length and total number of parasites in each organ examined.

\begin{tabular}{clcc}
\hline \multirow{2}{*}{ Organ } & Weight & Total length & $\begin{array}{c}\text { Standard } \\
\text { length }\end{array}$ \\
\cline { 2 - 4 } & 0.047 & 0.2495 & 0.236 \\
Stomach & 0.0454 & -0.1203 & -0.1097 \\
Anterior intestine & 0.0293 & -0.0258 & -0.0297 \\
Middle intestine & 0.134 & 0.1063 & 0.1621 \\
Posterior intestine & 0.134
\end{tabular}

cystacanth form of the parasite was present. Studies on the feeding habits of $H$. eques have shown that small crustaceans represent $77 \%$ of the food intake of this fish, and that these crustaceans contain the larvae of Q. nickoli, thus giving rise to the cystacanth form after ingestion (LOUREIRO-CRIPPA, 2006). These encysted forms give rise to the adults after the paratenic host has been ingested by the definitive host (EIRAS, 1994).

The prevalence of infection was significantly higher during the rainy season. Studies on the population dynamics of acanthocephalans in temperate regions have suggested that the life cycle of these parasites is related to the seasons, and may be influenced by the temperature, feeding habits of the host and periods of dry and rainy weather (LASEE, 1989). In our sample, 
the parasites were found in the middle and posterior intestine only during the rainy season. Malta et al. (2001) reported that the pyloric caecum was the preferred habitat in tambaquis (Colossoma macropomum) in situations of lower infestation, i.e. contrary to the present data. The infection level is related to whether the river is at flood levels at that time. Flooding may contribute towards higher abundance of infected crustaceans, therefore favoring a higher likelihood that the fish will ingest infected invertebrates. However, the preferred habitat remains uncertain.

Rosim et al. (2005) did not find any seasonality relating to infection by Quadrigyrus machadoi in Hoplias malabaricus. However, in that case, the results may have been influenced by the small numbers of fish caught during the rainy season, in comparison with the present study.

There was no correlation between infection levels and the total and standard lengths, or with the weight of the host fish. Similar results were found for Astronotus ocellatus infected by Polymorphus sp. in the Guandú River (AZEVEDO et al., 2007), while Fischer et al. (2004) observed a positive correlation between the total length of the host (Colossoma macropomum) and the intensity of infection due to the acanthocephalan Neoechinorhynchus buttnerae. According to Luque and Chaves (1999), these results are not surprising given that the parasitic infection does not necessarily increase with the length of the fish, but is related to the feeding habits in the different age classes of the host.

From the present data, it can be concluded that $H$. eques is a paratenic host for $Q$. nickoli in the study area, and that the parasite presents higher prevalence in the middle intestine of the host during the rainy season. Other aspects of the biology of this parasite and its relationship with the fish host will be elucidated in further studies.

\section{References}

Amato JFR, Boeger WA, Amato SB. Protocolos para laboratório: Coleta e processamento de parasitas de pescado. Rio de Janeiro; 1991. p. 1-52.

Azevedo RK, Abdallah VD, Luque JC. Ecologia da comunidade de metazoários de parasitos do Apaiarí Astronotus ocellatus (Cope, 1872) (Perciformes: Cichlidae) do Rio Guandu, Estado do Rio de Janeiro, Brasil. Rev Bras Parasitol Vet 2007; 16(1): 15-20. PMid:17588317.

Bush AO, Lafferty KD, Lotz JM, Shostak AW. Parasitology meets ecology on its owm terms: Margolis et al. revisited. J Parasitol 1997; 83(4): 575-583. PMid:9267395. http://dx.doi.org/10.2307/3284227

Cole B, Haring M. Spawing and Production of the Serpae Tetra, Hyphessobrycon serpae. Sea Grand Extension service, School of ocean and Earth Science and Technology. Center for Tropical and Subtropical. Aquaculture Publication; 1999. v. 138, p. 7.

Eiras JC. Elementos de Ictioparasitologia. Porto: Fundação Eng. António de Almeida; 1994. 339 p.

Eiras JC, Takemoto RM, Pavanelli GC. Métodos de estudo e técnicas laboratoriais em parasitologia de peixes. Maringá: Eduem; 2006. 199 p. PMCid:237164.

Fischer C, Malta JCO, Varella AMB. A fauna de parasitas do Tambaqui, Colossoma macropomum (Cuvier, 1818) (Characiformes: Characidae) do médio rio Solimóes, estado do Amazonas (AM) e do baixo rio Amazonas, estado do Pará (PA), e seu potencial como indicadores biológicos. Acta Amaz 2004; 33(4): 651-662.

Food and Agriculture Organization of the United Nations - FAO. The state of world fisheries and aquaculture [online] 2000 [cited 2007 Dec. 15]. Available from: http://www.fao.org/.

Freitas CEC, Rivas AAF. A pesca e os Recursos Pesqueiros da Amazônia Ocidental. Cienc Cult 2006; 58(3): 30-32.

Lasee BA. Seasonal population dynamics and maturation of Neoechinorhynchus pungitius (Acantocephala: Neoechinorhynchidae) infecting brook stickleback, Culaea inconstans, from Sioux Creek, Wisconsin, USA. Can J Zool 1989; 67(3): 590-595. http://dx.doi. org/10.1139/z89-085

Loureiro-Crippa VE. Dieta, Hábitos alimentares e morfologia trófica de peixes de pequeno porte, em lagoas da planície de inundação do alto Rio Paraná, Brasil [Dissertação]. Maringá: Universidade Estadual de Maringá; 2006.

Luque JL, Chaves ND. Ecologia da comunidade de metazoários parasitos da anchova Pomatomus saltator (Linnaeus) (Osteichthyes, Pomatomidae) do litoral do estado do Rio de Janeiro, Brasil. Rev Bras Zool 1999; 16(3): 711-723. http://dx.doi.org/10.1590/ S0101-81751999000300010

Luque JL. Parasitologia de peixes marinhos na América do Sul: Estado atual e perspectivas. In: Paiva MJT, Takemoto RM, Lizama MAP. Sanidade de organismos aquáticos. São Paulo: Ed. Varela; 2004. p. 199-214.

Malta JCO, Gomes ALS, Andrade SMS, Varella A MB. Infestações maciças por acantocéfalos, Neoechinorhynchus buttnerae Golvan, 1956, (Eoacanthocephala: Neoechinorhynchidae) em Tambaquis jovens, Colossoma macropomum (CUVIER, 1818) cultivados na Amazônia central. Acta Amaz 2001; 31(1): 133-143.

Martins ML, Moraes FR, Fujimoto RY, Onaka EM, Nomura DT, Silva $\mathrm{CAH}$, et al. Parasitic infections in cultivated brazilian freshwater fishes. A survey of diagnosticated cases from 1993 to 1998. Rev Bras Parasitol Vet 2000; 9(1): 23-28.

Rosim DF, Ceccarelli PS, Silva-Sousa AT. Parasitismo de Hoplias malabaricus (Bloch, 1794) (Characiformes: Erythrinidae) por Quadrigyrus machadoi Fábio, 1983 (Eoacanthocephala: Quadrigyridae) de uma lagoa em Aguaí, Estado de São Paulo, Brasil. Rev Bras Parasitol Vet 2005; 14(4): 147-153.

Schaeffer-Novelli Y, Cintron G. Guia para estudo de Áreas de Manguezal. São Paulo: Caribbean Ecological Research. 1986. 150 p.

Schmidt GD, Hugghins EJ. Acantocephala of South American fishes. Part.1, Eoacanthocephala. J Parasitol 1973; 59(5): 829-835. http://dx.doi. org/10.2307/3278417

Tavares-Dias M, Lemos JRG, Martins ML, Jerônimo GT. Metazoan and protozoan parasites of freshwater ornamental fish from Brazil. In: Tavares-Dias M. Manejo e sanidade de peixes em cultivo. Macapá: Embrapa Amapá; 2009. p. 469-494.

Tavares-Dias M, Lemos JRG, Martins ML. Parasitic fauna of eight species of ornamental freshwater fish species from the middle Negro River in the Brazilian Amazon region. Rev Bras Parasitol Vet 2010; 19(2): 103-107. PMid:20624347. http://dx.doi.org/10.4322/rbpv.01902007

Thacher VE. Amazon Fish Parasites. Manaus: Instituto Nacional de pesquisas da Amazônia; 2006. 555 p. 